\title{
Biosynthesis of copper carbonate nanoparticles by ureolytic fungi
}

\author{
Qianwei $\mathrm{Li}^{1,2} \cdot$ Geoffrey Michael Gadd ${ }^{1}$
}

Received: 25 May 2017 / Revised: 19 July 2017 / Accepted: 22 July 2017 / Published online: 10 August 2017

(C) The Author(s) 2017. This article is an open access publication

\begin{abstract}
In this research, the ureolytic fungi Neurospora crassa, Pestalotiopsis sp. and Myrothecium gramineum were investigated for the preparation of nanoscale copper carbonate and the role of fungal extracellular protein in such mineral formation. After incubation in urea-modified media, carbonate-laden fungal supernatants were used for the precipitation of copper carbonate, with experimental results agreeing closely with those obtained using geochemical modelling (Geochemist's Workbench). Compared with commercial and chemically synthesized copper carbonate, the minerals obtained using fungal supernatants were nanoscale and showed varying morphologies. It was found that extracellular protein played an important role in determining the size and morphology of the carbonate minerals precipitated, and after mixture with $\mathrm{CuCl}_{2}$ and resultant copper carbonate precipitation, more than $80 \%$ protein was removed from the $N$. crassa supernatant. Moreover, with addition of extracellular protein extracted from different fungal supernatants or standard bovine serum albumin, more than $96 \%$ of protein was removed by carbonate mineral precipitation. These results provide direct experimental evidence for the preparation of copper carbonate nanoparticles utilizing fungal ureolytic activity and show that fungal extracellular protein plays an important role in the formation and size of specific nano metal carbonates. Such a process provides
\end{abstract}

Geoffrey Michael Gadd

g.m.gadd@dundee.ac.uk

1 Geomicrobiology Group, School of Life Sciences, University of Dundee, Dundee, DD1 5EH, Scotland, UK

2 State Key Laboratory of Heavy Oil Processing, Beijing Key Laboratory of Oil and Gas Pollution Control, China University of Petroleum, 18 Fuxue Road, Changping District, Beijing 102249, People's Republic of China opportunities for production of specific and/or novel metal carbonate nanoparticles of applied relevance, and as precursors of other useful biomineral products such as oxides.

Keywords Ureolytic fungi · Copper carbonate · Extracellular protein $\cdot$ Biosynthesis

\section{Introduction}

Nanotechnology refers to the synthesis and exploitation of materials with at least one dimension in the nanometre range $(\leq 100 \mathrm{~nm})$ (Bhattacharya and Gupta 2005). Due to their novel optical (Królikowska et al. 2003), chemical (Kumar et al. 2003), photoelectrochemical (Chandrasekharan and Kamat 2000) and electronic (Pető et al. 2002) properties, much research has been carried out on the synthesis of nanomaterials including chemical composition, size and attainment of high monodispersity (Mandal et al. 2006). The synthesis of nanoparticles by chemical methods shows some advantages for large productivity within a relatively short time by adjusting the concentrations of reacting chemicals and controlling the reaction environment, while disadvantages include the high energy demand, cost and the use of extra toxic chemicals (Murray et al. 2000). Physical methods for nanoparticle production, e.g. sputter deposition, laser ablation, and cluster bean deposition, are often difficult (Gade et al. 2010). The development of reliable and environmentally friendly technologies for the synthesis of nanomaterials has therefore become an important aspect of nanotechnology.

It is well known that many microorganisms, including bacteria, yeasts and other fungi, are able to produce inorganic materials intracellularly or extracellularly at nanoscale and microscale (Bhattacharya and Gupta 2005; Gadd 2004, 
2010; Li et al. 2011). Salunke et al. (2015) compared the abilities of Saccharophagus degradans and Saccharomyces cerevisiae for the synthesis of manganese dioxide nanoparticles, and showed that $S$. cerevisiae could provide a simple and reliable approach for the production of this nanomaterial. The synthesis of gold nanoparticles has received considerable attention due to their unique and tunable surface plasmon resonance (SPR) (El-Sayed 2001) and their applications in biomedical science including drug delivery, tissue/tumour imaging, photothermal therapy and immunochromatographic identification of pathogens in clinical specimens (Huang 2006). He et al. (2007) demonstrated that gold nanoparticles $(10-20 \mathrm{~nm})$ were formed at $\mathrm{pH} 7$ by the bacterium Rhodopseudomonas capsulata based on the bioreduction of $\mathrm{AuCl}_{4}^{-}$. A lead-tolerant marine yeast strain Rhodosporidium diobovatum was used for the synthesis of lead sulphide nanoparticles, and it was found that the metallic $\mathrm{PbS}$ particles were formed intracellularly with a size range of $2-5 \mathrm{~nm}$ (Seshadri et al. 2011). Compared with bacteria and yeasts, the use of filamentous fungi for the synthesis of nanoparticles seems more promising since they are easily cultured under a controlled environment and can secrete large amounts of extracellular enzymes which are involved in nanomaterial synthesis (Mandal et al. 2006; Bansal et al. 2011).

Fungi can accumulate metals by a number of mechanisms including biosorption, complexation to metabolites and polymers, binding to specific polypeptides and metabolismdependent accumulation (Gadd 2007; Gade et al. 2010). Another broad mechanism of metal immobilization is through formation of elemental forms or biominerals by means of various redox transformations or excretion of metabolites (Gadd 2010). Most attention to date in the microbial context has focussed on elemental forms, especially silver. Extracellular synthesis of silver nanoparticles $(5-45 \mathrm{~nm})$ was achieved using the fungus Fusarium oxysporum when $10 \mathrm{~g}$ (wet weight) of biomass was exposed to an aqueous silver solution containing $1 \mathrm{mM} \mathrm{Ag}^{+}$: the particles were strongly stabilized by secreted proteins (Ahmad et al. 2003). Fungal supernatants from Penicillium brevicompactum WA 2315 cultures were also applied for the synthesis of silver nanoparticles, and the possibility of protein as a stabilizing material in the nanoparticles was revealed by Fourier transform infrared spectroscopy (FTIR) analysis (Shaligram et al. 2009). Several reports have pointed out the importance of extracellular proteins in the biosynthesis of nanoparticles, which has indicated an alternative means for their large-scale biosynthesis. Bansal et al. (2004) demonstrated that extracellular proteins, secreted by $F$. oxysporum, with a molecular weight around 24 to $28 \mathrm{kDa}$, were responsible for the biosynthesis of zirconia nanoparticles. Although much research has been carried out on the biosynthesis of metal nanoparticles (e.g. Au, Ag), and magnetic and non-magnetic oxide and sulphide nanoparticles, there is little knowledge about the biosynthesis of metal carbonate nanominerals and their potential. Metal carbonates can be a good precursor for preparation of metal oxides, especially for nanoscale transition metal oxides which are excellent candidates for electrode materials (Poizot et al. 2000; Dillon et al. 2008; Wu et al. 2012; Li et al. 2016). Copper oxide has attracted attention due to its diverse applications in gas sensors, catalysis, batteries, high-temperature superconductors, solar energy conversion and field emission emitters (Cava 1990; Tranquada et al. 1995; Ren et al. 2009). The ability of ureolytic microorganisms to precipitate carbonates is a well-known phenomenon. Such microbially-induced carbonate precipitation relies on the hydrolysis of urea leading to ammonium and carbonate formation, the latter precipitating with available metals to form carbonates (Kumari et al. 2016). It has been shown that this process can be used to prepare pure specific metal carbonates and that some of the biominerals thus produced may exhibit nanoscale dimensions ( $\mathrm{Li}$ et al. 2014, 2015). The aim of this research was to characterize nanoscale copper carbonate precipitated by ureolytic fungi and to investigate the influence of extracellular protein on the formation and morphology of such nanominerals.

\section{Materials and methods}

\section{Organisms and media}

The experimental fungi used were Neurospora crassa (WT FGSC no. 2489, Fungal Genetics Stock Centre (FGSC), Kansas, USA), Pestalotiopsis sp. and Myrothecium gramineum (isolated from calcareous soil; deposited in the Geomicrobiology Group Culture Collection) (Li et al. 2015). These were incubated on urea-modified AP1 agar plates at $25{ }^{\circ} \mathrm{C}$ in the dark for several days (3-4 days for $N$. crassa and Pestalotiopsis sp., 2 weeks for M. gramineum) prior to experimental subculture, and inoculation plugs were taken from the margins of actively growing colonies using a sterile (autoclaved at $121^{\circ} \mathrm{C}, 15 \mathrm{~min}$ ) cork borer ( $5 \mathrm{~mm}$ in diameter). All experiments were conducted at least in triplicate. Modified AP1 liquid medium was prepared according to Li et al. (2015).

\section{Identification of biominerals precipitated by fungal supernatants}

Minerals precipitated by fungal growth supernatants were collected for further examination using an environmental scanning electron microscope (ESEM) (Jeol JSM7400F) and energy-dispersive X-ray analysis (EDXA). Experimental procedures were carried out as described by Li et al. (2015).

For mineral particles in the nanoscale, morphological observations were carried out using a Jeol-1200 EX transmission electron microscope (TEM) (Jeol, Welwyn Garden City, UK). 
About $10 \mathrm{mg}$ of nanoscale particles was suspended in an Eppendorf tube containing $1 \mathrm{ml}$ Milli-Q water, and $2 \mu \mathrm{l}$ of the suspension was placed on "holey" carbon-coated nickel grids (Agar Scientific Ltd., Colchester, Essex, UK) and allowed to evaporate prior to TEM analysis.

FTIR was carried out for further identification of metal carbonates with sample preparation according to the procedure described in Li et al. (2015).

\section{Quantification of extracellular proteins produced by ureolytic fungi}

Fungal growth supernatant was collected by centrifugation $\left(4770 \mathrm{~g} \times 20 \mathrm{~min}, 4{ }^{\circ} \mathrm{C}\right)$, and the concentration of extracellular protein was measured using the Coomassie (Bradford) Protein Assay Kit (Thermo Fisher Scientific Inc., Waltham, MA, USA). According to the protocol provided, $100 \mu \mathrm{l}$ fungal growth supernatant was mixed well with $100 \mu \mathrm{l}$ Coomassie reagent in a 96-well plate (Thermo Fisher Scientific Inc., USA) and left for $15 \mathrm{~min}$. The absorbance was measured at $595 \mathrm{~nm}$ using a $\mu$ Quant microplate spectrophotometer (BioTek Instruments, Inc., Winooski, VT, USA). Protein concentrations were estimated by reference to the absorbance obtained for a dilution series of bovine serum albumin (BSA) standards (Thermo Fisher Scientific Inc., USA).

\section{Geochemical modelling of copper carbonate precipitation using the Geochemist's Workbench (GWB)}

The Geochemist's Workbench (GWB, 10.0.6) (Aqueous Solutions LLC, Urbana-Champaign, USA) is a set of software tools for manipulating chemical reactions, calculating stability diagrams and the equilibrium states of natural waters, tracing reaction processes, modelling reactive transport, plotting the results of these calculations and storing the related data. The GWB Essentials release contains six programs, GSS, Rxn, Act2, Tact, SpecE8 and Gtplot. For example, Act2 is a programme that calculates and plots activity-activity diagrams, which shows the stability of minerals and the predominant aqueous species in chemical systems. In this diagram, the axis variable can be species activity, gas fugacity, activity or fugacity ratio, $\mathrm{pH}$, Eh or pe (electronic activity). SpectE8 models the equilibrium state of geochemical systems that contain an aqueous fluid, including the equilibrium distribution of aqueous species, the fluid's saturation state with respect to minerals, the sorption of aqueous species onto various surfaces and the fugacity of gases dissolved in the fluid (https://www.gwb.com/Student/index.php).

\section{Results}

\section{Geochemical modelling of copper carbonate precipitation using Geochemist's workbench (GWB)}

The Geochemist's workbench (GWB) is a useful geochemical modelling software package for calculating activity-activity and temperature-activity diagrams, the equilibrium state of natural fluids and theoretical systems and reaction path modelling (Kaszuba and Runde 1999; Cleverley and Bastrakov 2005; Gallios and Vaclavikova 2008). Previous research has demonstrated that carbonate-laden fungal growth supernatants can provide a useful method for the precipitation of certain metal carbonates. The GWB software was applied to simulate the precipitation of copper carbonate in order to provide more theoretical understanding of the bioprecipitation of specific metal carbonates over a range of physico-chemical conditions. In these experiments, the solubility and stability of $\mathrm{Cu}^{2+}$ and relevant $\mathrm{Cu}$-containing minerals and the predominance of aqueous $\mathrm{Cu}$ species were calculated individually in a simulated fungal growth supernatant system using the GWB SpecE8 and Act2 programs (Fig. 1). The simulated fungal supernatant system was set at $40 \mathrm{mM} \mathrm{CO}_{3}{ }^{2-}, 80 \mathrm{mM} \mathrm{NH}_{4}{ }^{+}, 4 \mathrm{mM} \mathrm{KCl}$, $0.8 \mathrm{mM} \mathrm{MgSO}_{4} \cdot 7 \mathrm{H}_{2} \mathrm{O}, 1.7 \mathrm{mM} \mathrm{NaCl}, 0.2 \mathrm{mM} \mathrm{CaCl}_{2} \cdot 6 \mathrm{H}_{2} \mathrm{O}$, $9 \mu \mathrm{M} \mathrm{FeCl}_{3} \cdot 6 \mathrm{H}_{2} \mathrm{O}, 0.01 \mathrm{mM} \mathrm{ZnSO} \cdot 7 \mathrm{H}_{2} \mathrm{O}$ and $0.02 \mathrm{mM}$

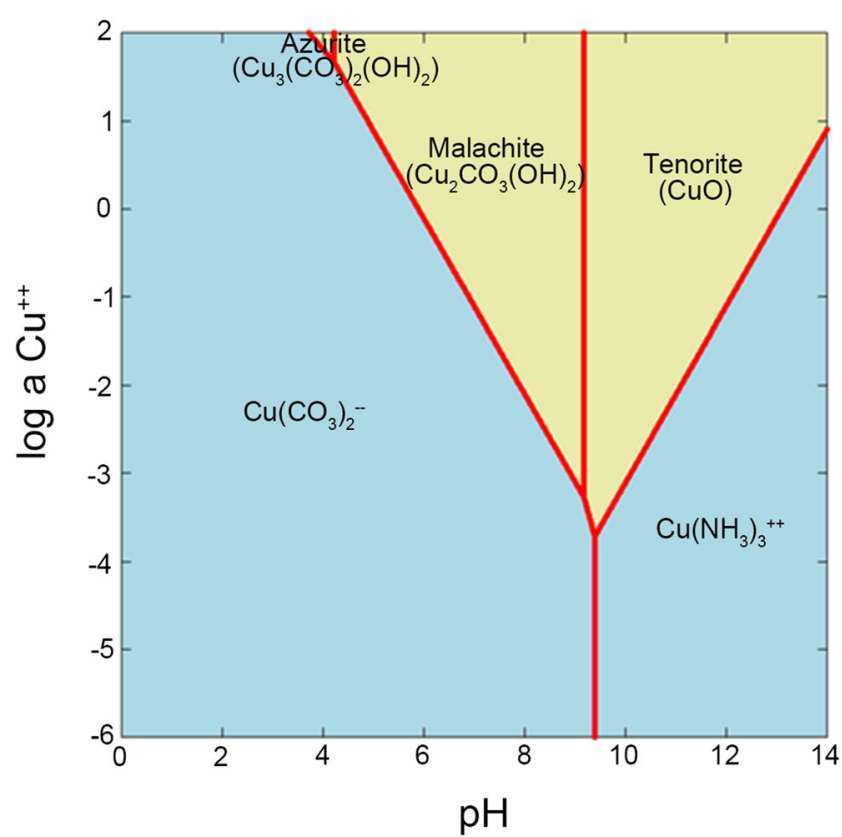

Fig. 1 Solubility diagram of $\mathrm{Cu}^{2+}$ versus $\mathrm{pH}$ at $25^{\circ} \mathrm{C}$ in a simulated fungal growth supernatant system. In this model, the solubility and stability of $\mathrm{Cu}^{2+}$ and relevant $\mathrm{Cu}$-containing minerals and the predominance of aqueous $\mathrm{Cu}$ species were calculated individually in a simulated fungal growth supernatant system using GWB SpecE8 and Act2 programs. The simulated fungal supernatant system was set at $40 \mathrm{mM} \mathrm{CO}_{3}{ }^{2-}, 80 \mathrm{mM} \mathrm{NH}_{4}{ }^{+}, 4 \mathrm{mM} \mathrm{KCl}, 0.8 \mathrm{mM} \mathrm{MgSO}_{4} \cdot 7 \mathrm{H}_{2} \mathrm{O}$, $1.7 \mathrm{mM} \mathrm{NaCl}, 0.2 \mathrm{mM} \mathrm{CaCl} \cdot 6 \mathrm{H}_{2} \mathrm{O}, 9 \mu \mathrm{M} \mathrm{FeCl} \cdot 6 \mathrm{H}_{2} \mathrm{O}, 0.01 \mathrm{mM}$ $\mathrm{ZnSO}_{4} \cdot 7 \mathrm{H}_{2} \mathrm{O}$ and $0.02 \mathrm{mM} \mathrm{MnSO}{ }_{4} \cdot 4 \mathrm{H}_{2} \mathrm{O}$ at $25^{\circ} \mathrm{C}$ 
$\mathrm{MnSO}_{4} \cdot 4 \mathrm{H}_{2} \mathrm{O}$ at $25{ }^{\circ} \mathrm{C}$. The results showed that the precipitation of different metal carbonates only occurred at certain metal and carbonate concentrations and $\mathrm{pH}$ range. At given physico-chemical conditions, several copper-containing species may occur in the aqueous system. The model diagram indicated that malachite $\left(\mathrm{Cu}_{2} \mathrm{CO}_{3}(\mathrm{OH})_{2}\right)$ might occur as the dominant mineral over the $\mathrm{pH}$ range of 4.2-9.2, at certain concentrations of $\mathrm{Cu}^{2+}$, while precipitation of tenorite $(\mathrm{CuO})$ occurred at higher $\mathrm{pH}$ values (above $\mathrm{pH}$ 9). According to the solubility diagram, the precipitation of azurite $\left(\mathrm{Cu}_{3}\left(\mathrm{CO}_{3}\right)_{2}(\mathrm{OH})_{2}\right)$ can only occur over a narrow $\mathrm{pH}$ range $(\mathrm{pH} \approx 3.8-4.2)$ when the concentration of $\mathrm{Cu}^{2+}$ is unfeasibly high. In nature, malachite and azurite can be found on weathered brass, bronze copper (Schweitzer 2004). Azurite is unstable in the open air with respect to malachite, and often is pseudomorphically replaced by malachite:

$$
2 \mathrm{Cu}_{3}\left(\mathrm{CO}_{3}\right)_{2}(\mathrm{OH})_{2}+\mathrm{H}_{2} \mathrm{O} \rightarrow 3 \mathrm{Cu}_{2}\left(\mathrm{CO}_{3}\right)(\mathrm{OH})_{2}+\mathrm{CO}_{2}
$$

\section{Characteristics of copper carbonate precipitated by fungal growth supernatants}

In these experiments, ureolytic fungi were grown in modified AP1 liquid media for several days at $25{ }^{\circ} \mathrm{C}$ (12 days for N. crassa, 14 days for Pestalotiopsis sp., 23 days for $M$. gramineum) and the fungal growth supernatant containing carbonate was collected by centrifugation $(4770 \mathrm{~g} \times 20 \mathrm{~min}$, $\left.4{ }^{\circ} \mathrm{C}\right) .50 \mathrm{mM} \mathrm{CuCl}_{2}$ was mixed with different fungal growth supernatants $(v / v=1: 1)$ for the precipitation of metal carbonates. Minerals precipitated were collected by centrifugation $\left(12,000 \mathrm{~g} \times 5 \mathrm{~min}, 4{ }^{\circ} \mathrm{C}\right)$, washed twice by resuspending in Milli-Q and recentrifuging and then dried in a desiccator for a week at room temperature. The results showed that after mixture with the fungal growth supernatants, granular particles were produced and the dimensions of these were nanoscale (Fig. 2). TEM revealed that the minerals precipitated by $N$. crassa supernatant when mixed with $\mathrm{CuCl}_{2}$ were around $10-20 \mathrm{~nm}$ in diameter (Fig. 3). EDXA showed that the elemental composition of the minerals precipitated using the different fungal growth supernatants was the same in each case with the main elements being $\mathrm{C}, \mathrm{O}$ and $\mathrm{Cu}$ (Fig. 4).

FTIR was applied to assist the identification of $\mathrm{Cu}$ containing minerals due to their amorphous pattern in X-ray diffraction (XRD) analysis. Commercial basic copper carbonate was used as a control for mineral identification (Fig. 5). Basic copper carbonate normally refers to the compound $\mathrm{Cu}_{2}(\mathrm{OH})_{2} \mathrm{CO}_{3}$ (the mineral malachite). Sometimes, this name is also used for $\mathrm{Cu}_{3}(\mathrm{OH})_{2}\left(\mathrm{CO}_{3}\right)_{2}$ (the related mineral azurite). Table 1 shows the infrared spectra peaks and intensities of malachite and azurite (Huang and Kerr 1960) which provides information about the differences between these two minerals.
According to Fig. 5, the main peaks of the control sample centred at $\sim 3266,1501,1391,953,862,834,743$ and $713 \mathrm{~cm}^{-1}$. Compared with the spectral data in Table 1, the commercial basic copper carbonate used should therefore be described as a mixture of malachite and azurite. Similarly, the $\mathrm{Cu}$-containing minerals precipitated by the growth supernatants of N. crassa and Pestalotiopsis sp. were malachite with a trace amount of azurite while minerals precipitated by the supernatant of $M$. gramineum were solely malachite. Moreover, when the supernatant was mixed with $\mathrm{CuCl}_{2}$, the $\mathrm{pH}$ of the mixture decreased from $\mathrm{pH} 8-9$ to $\mathrm{pH} 6$ and, according to the solubility diagram, when the concentration of $\mathrm{Cu}^{2+}$ in the solution was $\sim 50 \mathrm{mM}$, malachite $\left(\mathrm{Cu}_{2} \mathrm{CO}_{3}(\mathrm{OH})_{2}\right)$ was the dominant mineral over the $\mathrm{pH}$ range of 6 to 9.2 which agreed very well with the data from the FTIR results.

\section{Characteristics of commercial and chemically synthesized copper carbonates}

Although sharing the same chemical formulae, minerals with different morphologies may show varying physical properties. To compare the differences between carbonate minerals synthesized using different methods, the morphology of commercial and chemically synthesized copper carbonate was investigated by SEM (Fig. 6). The morphology of commercial copper carbonate was found to be spherical with two different surfaces. One type of mineral contained compact short mineral columns which distributed evenly forming a smooth surface (Fig. 6a). The other type contained rodshaped minerals which distributed loosely forming a rough surface (Fig. 6b). $50 \mathrm{mM} \mathrm{CuCl} 2$ was mixed with $50 \mathrm{mM}$ $\left(\mathrm{NH}_{4}\right)_{2} \mathrm{CO}_{3}(v / v=1: 1)$ for the precipitation of copper carbonate. The results showed that chemically synthesized copper carbonate was spherical with smooth or rough surfaces ( $300 \mathrm{~nm}$ in diameter) (Fig. 6c, d).

\section{Extracellular proteins in fungal growth supernatants}

Although the GWB software was applied as a useful method to predict and/or confirm the final products of the biomineralization process, little attention has been paid to the clear differences in morphology and size between biogenic minerals and commercial or chemically synthesized minerals. In these experiments, the possible role of extracellular protein was investigated in relation to the precipitation of nanoscale metal carbonates.

The Bradford method was used for the detection and quantification of fungal extracellular protein. The results showed that the highest concentration of extracellular protein produced by $M$. gramineum was about $24 \mu \mathrm{g} \mathrm{ml}^{-1}$ while proteins produced by $N$. crassa and Pestalotiopsis sp. were 14 and $9 \mu \mathrm{g} \mathrm{ml}^{-1}$, respectively (Table 2). After mixture with $50 \mathrm{mM}$ $\mathrm{CuCl}_{2}$ and copper carbonate precipitation, the concentration 
Fig. 2 Scanning electron microscopy of minerals precipitated by a mixture of different fungal supernatants and $\mathrm{CuCl}_{2}$ solutions. Images show minerals precipitated by $50 \mathrm{mM}$ $\mathrm{CuCl}_{2}$ when mixed with supernatants of a $N$. crassa, b M. gramineum, and $\mathbf{c}, \mathbf{d}$ Pestalotiopsis sp. grown in modified AP1 medium. Scale bars: $\mathbf{a}-\mathbf{c}=1 \mu \mathrm{m}, \mathbf{d}=500 \mathrm{~nm}$. Typical images are shown from many similar examples
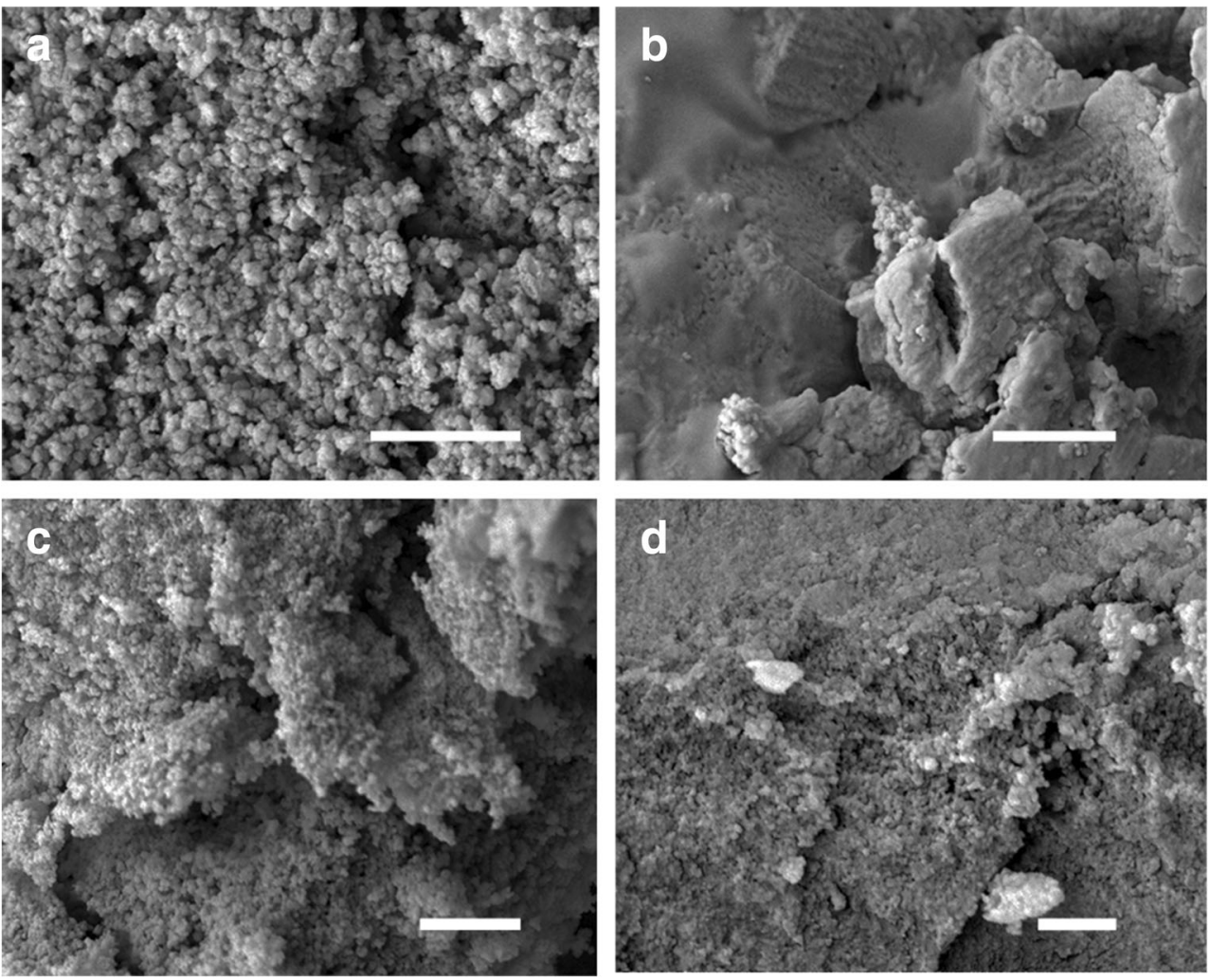

of extracellular protein in the fungal supernatant decreased to different levels. Compared with the other two fungal species, more protein was removed $(\sim 80 \%)$ from the supernatant of $N$. crassa after mixing with $\mathrm{CuCl}_{2}$ solution, while for the supernatant of $M$. gramineum, only $23 \%$ of protein was removed (Table 2).

\section{Mineral precipitation in the presence of fungal extracellular protein}

To obtain pure and concentrated extracellular protein, fungal growth supernatants collected by centrifugation $\left(4770 \mathrm{~g} \times 30 \mathrm{~min}, 4{ }^{\circ} \mathrm{C}\right.$ ) were re-centrifuged $\left(4770 \mathrm{~g} \times 30 \mathrm{~min}, 4{ }^{\circ} \mathrm{C}\right)$ with a Vivaspin protein concentrator spin column (molecular weight cut-off 5000) (Sartorius Stedim Biotech, Göttingen, Germany) until the final volume of supernatant was around $2 \mathrm{ml}$. To investigate the role of extracellular protein on mineral morphology, standard bovine serum albumin (BSA) and concentrated extracellular protein (3.10 mg ml $\mathrm{mg}^{-1}$ for $N$. crassa, $1.22 \mathrm{mg} \mathrm{ml}^{-1}$ for Pestalotiopsis sp., $5.13 \mathrm{mg} \mathrm{ml}^{-1}$ for M. gramineum) diluted to an appropriate concentration with Milli-Q water were mixed with $50 \mathrm{mM}$ $\mathrm{CuCl}_{2}$, and then added to $50 \mathrm{mM}\left(\mathrm{NH}_{4}\right)_{2} \mathrm{CO}_{3}$ for the precipitation of metal carbonates. In the presence of fungal extracellular protein or BSA, all the minerals precipitated were in the nanoscale (Fig. 7). The minerals precipitated with addition of protein solution from $M$. gramineum were around $40 \mathrm{~nm}$ in diameter (Fig. 7c), almost three times smaller than the
Fig. 3 Transmission electron microscopy of minerals precipitated by mixture of $\mathrm{CuCl}_{2}$ solutions and the growth supernatant of $N$. crassa. Scale bars: $\mathbf{a}=600 \mathrm{~nm}, \mathbf{b}=200 \mathrm{~nm}$. Typical images are shown from many similar examples
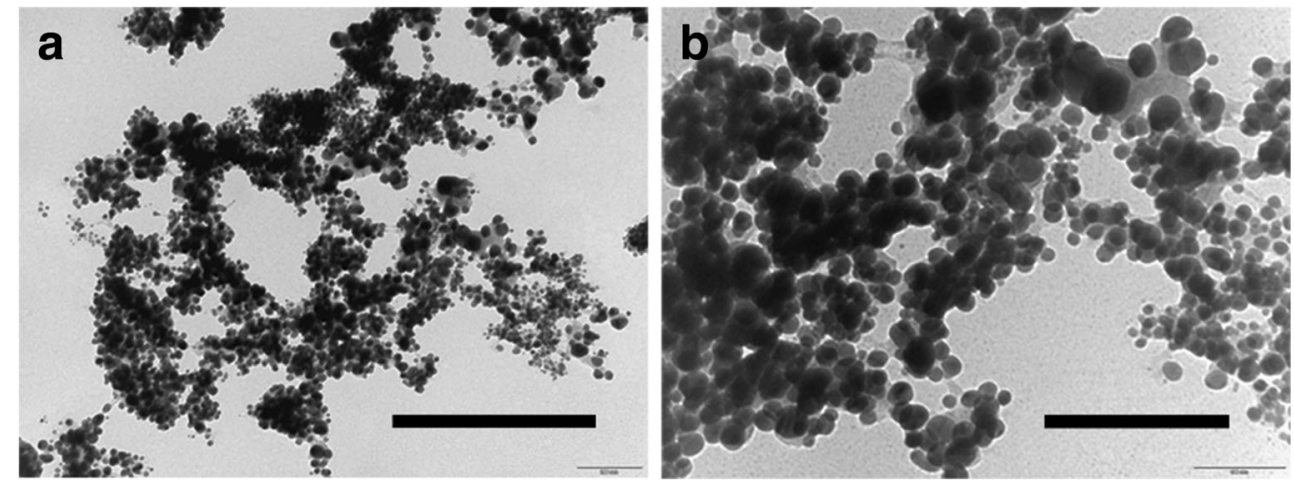


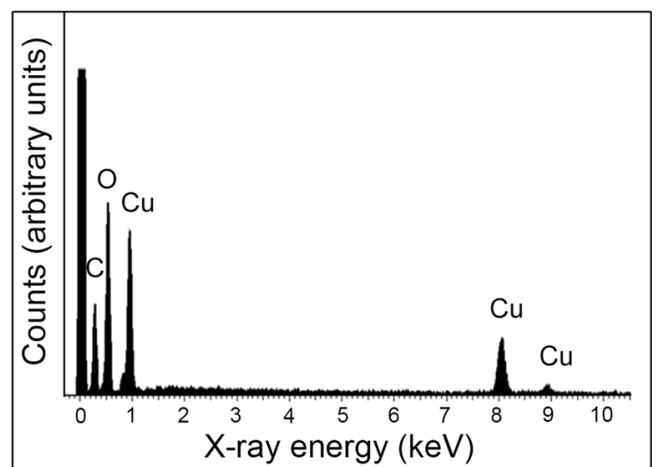

Fig. 4 Energy-dispersive X-ray analysis of minerals precipitated by the supernatant of $N$. crassa when mixed with $50 \mathrm{mM} \mathrm{CuCl}_{2}$. Typical spectra are shown from one of several determinations

minerals precipitated with the addition of the other fungal proteins (Fig. 7a, b). Moreover, these minerals of smaller size formed spherical aggregates around $150 \mathrm{~nm}$ in diameter (Fig. $7 \mathrm{a}, \mathrm{b}$ ). In the presence of standard BSA, the minerals precipitated were around $35 \mathrm{~nm}$ in diameter which was similar to the minerals precipitated by proteins from M. gramineum (Fig. 7d).

After mixture, the concentration of protein in the solutions was measured and it was found that less protein was removed by the addition of $\left(\mathrm{NH}_{4}\right)_{2} \mathrm{CO}_{3}$ to the protein solution (Table 3). More than $40 \%$ protein was removed from solution when added with $\mathrm{CuCl}_{2}$, except for the mixture containing BSA. When added with $\mathrm{CuCl}_{2}$ and $\left(\mathrm{NH}_{4}\right)_{2} \mathrm{CO}_{3}$, little protein was detected in the mixture and more than $96 \%$ protein was removed (Table 3).

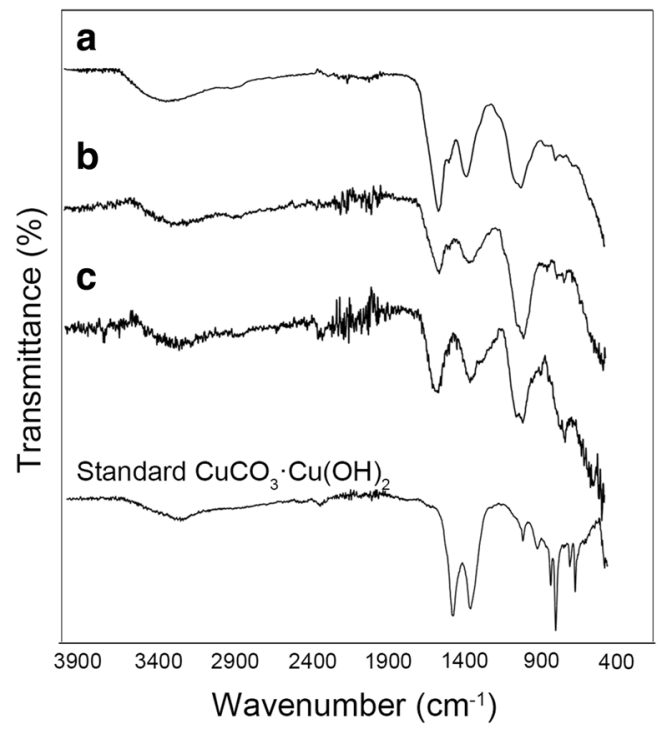

Fig. 5 Fourier transform infrared spectroscopy of $\mathrm{Cu}$-containing minerals precipitated by the fungal supernatants of a $N$. crassa, b Pestalotiopsis sp. and c $M$. gramineum when mixed with $50 \mathrm{mM}$ $\mathrm{CuCl}_{2}$. Commercial basic copper carbonate $\left(\mathrm{CuCO}_{3} \cdot \mathrm{Cu}(\mathrm{OH})_{2}\right)$ was used as a standard. Typical spectra are shown from one of several determinations

\section{Discussion}

Many techniques have been explored for the synthesis of nanomaterials, especially those using a biological template (Flynn et al. 2003; Royston et al. 2008; Shim et al. 2010; Sun et al. 2013). In comparison with materials produced by chemical and physical approaches, biominerals produced by biomineralization processes provide excellent physicochemical characteristics as well as biological properties, which may, in part, be due to the various functional groups associated with organic substances (Ryu et al. 2010). In this work, we have investigated the production of nanoscale copper carbonate precipitated by fungal supernatants.

Ureolytic microorganisms have been shown to be promising candidates for the formation of metal carbonates (Ferris et al. 2004; Ghashghaei and Emtiazi 2013; Phillips et al. 2013; Li et al. 2014, 2015, 2016; Kumari et al. 2016). Previous research has demonstrated that $N$. crassa was particularly effective for precipitation of $\mathrm{CaCO}_{3}$ and over $90 \%$ of supplied calcium $(50 \mathrm{mM})$ was precipitated as calcite $\left(\mathrm{CaCO}_{3}\right)(\mathrm{Li}$ et al. 2014). Such performance of urease-positive fungi incubated in urea-containing media provided an alternative technique for the synthesis of other metal carbonates. For example, $\sim 50 \%$ of cadmium, supplied at a high concentration $(0.5 \mathrm{M})$, was precipitated as pure otavite $\left(\mathrm{CdCO}_{3}\right)$, with microscale or nanoscale structures, by culture supernatants obtained after growth of $N$. crassa in urea-supplemented medium ( $\mathrm{Li}$ et al. 2014). Other urease-positive fungi (Pestalotiopsis sp. and M. gramineum), isolated from calcareous soil, were also applied for the precipitation of $\mathrm{Ca}$ and $\mathrm{Sr}$ carbonates, and the final minerals produced included $\mathrm{CaCO}_{3}, \mathrm{SrCO}_{3}, \mathrm{Sr}$ containing vaterite $\left(\left(\mathrm{Ca}_{\mathrm{x}} \mathrm{Sr}_{1-\mathrm{x}}\right) \mathrm{CO}_{3}\right)$ and the rare mineral olekminskite $\left(\mathrm{Sr}(\mathrm{Sr}, \mathrm{Ca})\left(\mathrm{CO}_{3}\right)_{2}\right)$ ( $\mathrm{Li}$ et al. 2015). Moreover, fungal supernatants obtained after growth of ureolytic fungi in urea-modified media were also applied as an alternative method for the precipitation of other metal carbonates, with applications for the biorecovery of valuable metals, and preparation of electrochemically active metal oxides using the metal carbonate precursor ( $\mathrm{Li}$ et al. 2014, 2015, 2016). In the experiments described here, different fungal growth supernatants were used for the precipitation of copper carbonates. The results showed that copper carbonates of various morphologies and sizes were precipitated after the mixture of different fungal growth supernatants and $\mathrm{CuCl}_{2}$ solutions. The precipitation process was simulated using GWB including parameters based on experimental data. The results showed that precipitation of copper carbonate strictly depended on the concentration of $\mathrm{Cu}^{2+}$ as well as the $\mathrm{pH}$ of the system. For example, at $\mathrm{pH} 8$, copper carbonate precipitated only when the concentration of $\mathrm{Cu}^{2+}$ was above $3 \mathrm{mM}$. Thus, the solubility diagrams calculated according to the thermodynamic data within the GWB software can provide theoretical evidence for the precipitation of specific metal carbonates. 
Table 1 Positions and intensities of absorption bands for copper carbonates using a PerkinElmer Model 21 double beam recording infrared spectrophotometer (adapted from Huang and Kerr 1960)

\begin{tabular}{|c|c|c|c|c|c|c|c|c|c|c|}
\hline \multirow{2}{*}{$\begin{array}{l}\text { Minerals } \\
\text { Malachite (green) } \mathrm{Cu}_{2} \mathrm{CO}_{3}(\mathrm{OH})_{2}\end{array}$} & \multicolumn{10}{|c|}{ Position of absorption bands $\left(\mathrm{cm}^{-1}\right)$} \\
\hline & $3510 \mathrm{~S}$ & & 1510 & $\begin{array}{l}1430 \mathrm{M} \\
1395 \mathrm{~S}\end{array}$ & $\begin{array}{l}1099 \\
1050 \mathrm{~S}\end{array}$ & & $873 \mathrm{M}$ & $\begin{array}{l}822 \mathrm{M} \\
775 \mathrm{~W}\end{array}$ & $750 \mathrm{~W}$ & $712 \mathrm{~W}$ \\
\hline Azurite (blue) $\mathrm{Cu}_{3}\left(\mathrm{CO}_{3}\right)_{2}(\mathrm{OH})_{2}$ & $3520 \mathrm{~S}$ & $1852 \mathrm{~W}$ & $\begin{array}{l}1509 \\
1475 \mathrm{~W}\end{array}$ & $1422 \mathrm{~S}$ & $1093 \mathrm{~W}$ & $955 \mathrm{~S}$ & $835 \mathrm{~S}$ & $817 \mathrm{M}$ & $\begin{array}{l}769 \mathrm{~W} \\
743 \mathrm{~W}\end{array}$ & \\
\hline
\end{tabular}

$W$ weak, $S$ strong, $M$ medium

An organic matrix (protein and/or other biological macromolecules) can play an important role in certain biomineralization processes, regulating and controlling nucleation and growth of the inorganic structure (Aizenberg et al. 1996; Cha et al. 1999; Klaus et al. 1999; Kröger et al. 1999; Naik et al. 2002). Compared with commercial and chemically synthesized carbonates, a large proportion of the copper carbonates precipitated by the fungal growth supernatants showed a nanoscale character (the minimum size was around $10 \mathrm{~nm}$ ), which may be related to the presence of extracellular protein in the growth supernatant. Several studies have demonstrated that proteins from living organisms can be employed as enzymes or templates for the synthesis of biominerals, even for minerals in the nanoscale (Douglas et al. 2002; Lee et al. 2002; Naik et al. 2002; Zhang 2003). Alexeev et al. (2003) showed that a ferric ion-binding protein from Neisseria gonorrhoeae readily bound clusters of $\mathrm{Fe}^{3+}, \mathrm{Ti}^{4+}, \mathrm{Zr}^{4+}$ or $\mathrm{Hf}^{4+}$ in solution which indicated a novel metal uptake mechanism and provided a model for protein-mediated biomineralization/dissimilation. Bovine serum albumin (BSA) was selected as a model protein for the synthesis of gold nanoclusters (NCs): prepared BSA-Au NCs were highly stable both in solution and in solid form (Xie et al. 2009). Naik et al. (2002) also described the in vitro biosynthesis of silver nanoparticles using silver-binding peptides identified from a combinatorial phage display peptide library. In our experiments, varying concentrations of extracellular protein were detected in the fungal growth supernatants depending on the organism and incubation time. When extracellular protein from fungal supernatants or standard BSA was mixed with $\mathrm{CuCl}_{2}$ and $\left(\mathrm{NH}_{4}\right)_{2} \mathrm{CO}_{3}$, nanoscale $\mathrm{Cu}$-containing minerals were produced and more than $96 \%$ of extracellular protein or BSA
Fig. 6 Scanning electron microscopy of $\mathbf{a}, \mathbf{b}$ commercial basic copper carbonate and $\mathbf{c}, \mathbf{d}$ copper carbonates precipitated by mixture of $\left(\mathrm{NH}_{4}\right)_{2} \mathrm{CO}_{3}$ and $\mathrm{CuCl}_{2}$. Scale bars: $\mathbf{a}=50 \mu \mathrm{m}$, inset $=2 \mu \mathrm{m} ; \mathbf{b}=30 \mu \mathrm{m}$, inset $=4 \mu \mathrm{m} ; \mathbf{c}=4 \mu \mathrm{m} ; \mathbf{d}=2 \mu \mathrm{m}$. Typical images are shown from many similar examples
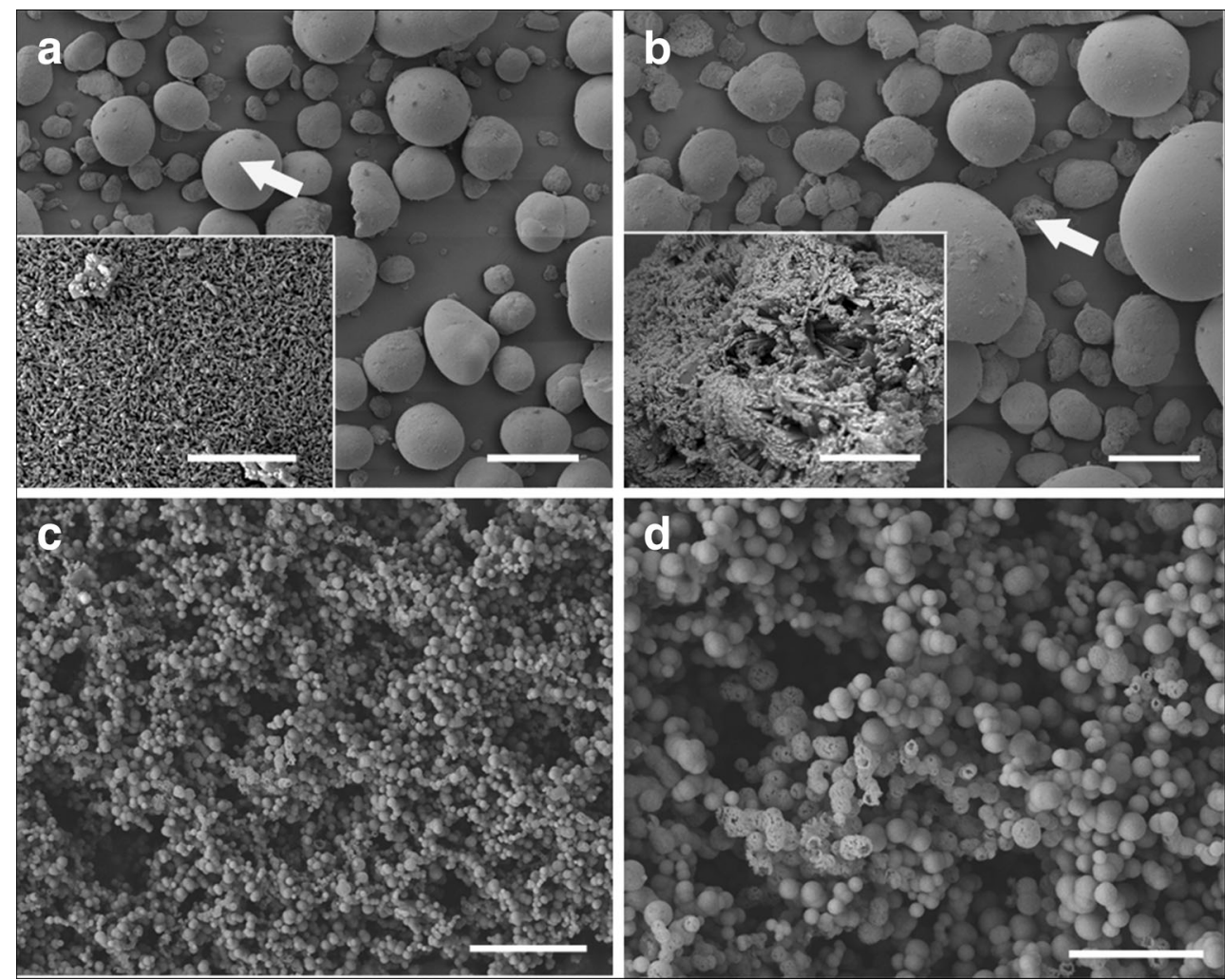
Table 2 Concentrations of extracellular protein produced by fungi and removal by copper carbonate precipitation

\begin{tabular}{llll}
\hline Fungal species & $\begin{array}{l}\text { Total extracellular } \\
\text { protein produced } \\
\text { by fungi } \\
\left(\mu \mathrm{g} \mathrm{ml}^{-1}\right)\end{array}$ & $\begin{array}{l}\text { Protein } \\
\text { remaining in } \\
\text { the supernatant } \\
\left(\mu \mathrm{g} \mathrm{ml}^{-1}\right)\end{array}$ & $\begin{array}{l}\text { Proportion of } \\
\text { protein removed } \\
\text { by mineral } \\
\text { precipitation }(\%)\end{array}$ \\
\hline $\begin{array}{l}\text { N. crassa } \\
\text { Pestalotiopsis } \\
\text { sp. }\end{array}$ & $14.25 \pm 0.26$ & $2.94 \pm 0.09$ & 80.2 \\
$\begin{array}{c}\text { M. gramineum } \\
\text { gramen }\end{array}$ & $24.11 \pm 1.12$ & $20.07 \pm 0.15$ & 48.2 \\
\hline
\end{tabular}

All fungi were incubated in modified AP1 liquid medium at $25^{\circ} \mathrm{C}$ in the dark for several days ( 12 days for $N$. crassa, 14 days for Pestalotiopsis sp. and 23 days for $M$. gramineum), and the supernatant was collected by centrifugation $\left(4770 \mathrm{~g} \times 20 \mathrm{~min}, 4^{\circ} \mathrm{C}\right) .50 \mathrm{mM} \mathrm{CuCl}_{2}$ was mixed with the different fungal growth supernatants $(v / v=1: 1)$ for the precipitation of copper carbonate. The quantification of extracellular protein was carried out before and after the mixture. Measurements were taken from at least three replicates, and the values indicate the standard error of the mean

was removed from solution by the carbonate precipitation. In the presence of $\mathrm{CuCl}_{2}$, more than $40 \%$ of fungal extracellular protein was removed from the mixture. It is well known that different proteins or peptides show various affinities for different metal ions which is based on the interaction between an electron-donating group on a protein surface and the accessible coordination sites of the metal ion (Ueda et al. 2003). Amino acids such as histidine (Arnold 1991; Wong et al.
1991; Gutiérrez et al. 2007), tryptophan (Horrocks and Collier 1981) and cysteine (Hansen et al. 1996), are key contributors to protein-metal binding (Porath et al. 1975; Ueda et al. 2003). In our experiments, the metal ion $\left(\mathrm{Cu}^{2+}\right)$-extracellular protein complex might serve as a nucleation site, which then reacts with available $\mathrm{CO}_{3}{ }^{2-}$ in solution for the precipitation of metal carbonates. Such protein binding to the metal ions might limit the subsequent growth of minerals resulting in the formation of nanoscale minerals.

Compared with geological or abiotic counterparts, biogenic minerals often show different morphologies, crystal habits and material properties (Nudelman and Sommerdijk 2012). This is not only due to the ionic composition of the medium but also the specialized macromolecules such as polysaccharides and proteins which can act as promoters or inhibitors of crystal nucleation, growth and phase transformations (Addadi and Weiner 1985; Addadi et al. 1987; Falini et al. 1996; Weiner and Addadi 1997; Nudelman and Sommerdijk 2012). This research has demonstrated that fungal metabolites, especially extracellular protein, can play an important role in the precipitation and morphology of metal carbonates, providing a potentially useful approach for the synthesis of specific metal carbonate nanoparticles. It is also concluded that geochemical modelling of metal speciation and mineral precipitation can provide useful theoretical support to identify physicochemical conditions for optimal synthesis of desired nanoscale metal carbonates.
Fig. 7 Scanning electron microscopy of $\mathrm{Cu}$-containing minerals precipitated by mixture of $\left(\mathrm{NH}_{4}\right)_{2} \mathrm{CO}_{3}$ and $\mathrm{CuCl}_{2}$ in the presence of proteins extracted from fungal growth supernatant of a N. crassa, b Pestalotiopsis sp., c M. gramineum, and d bovine serum albumin (BSA) standard solutions. Scale bars $=500 \mathrm{~nm}$. Typical images are shown from many similar examples
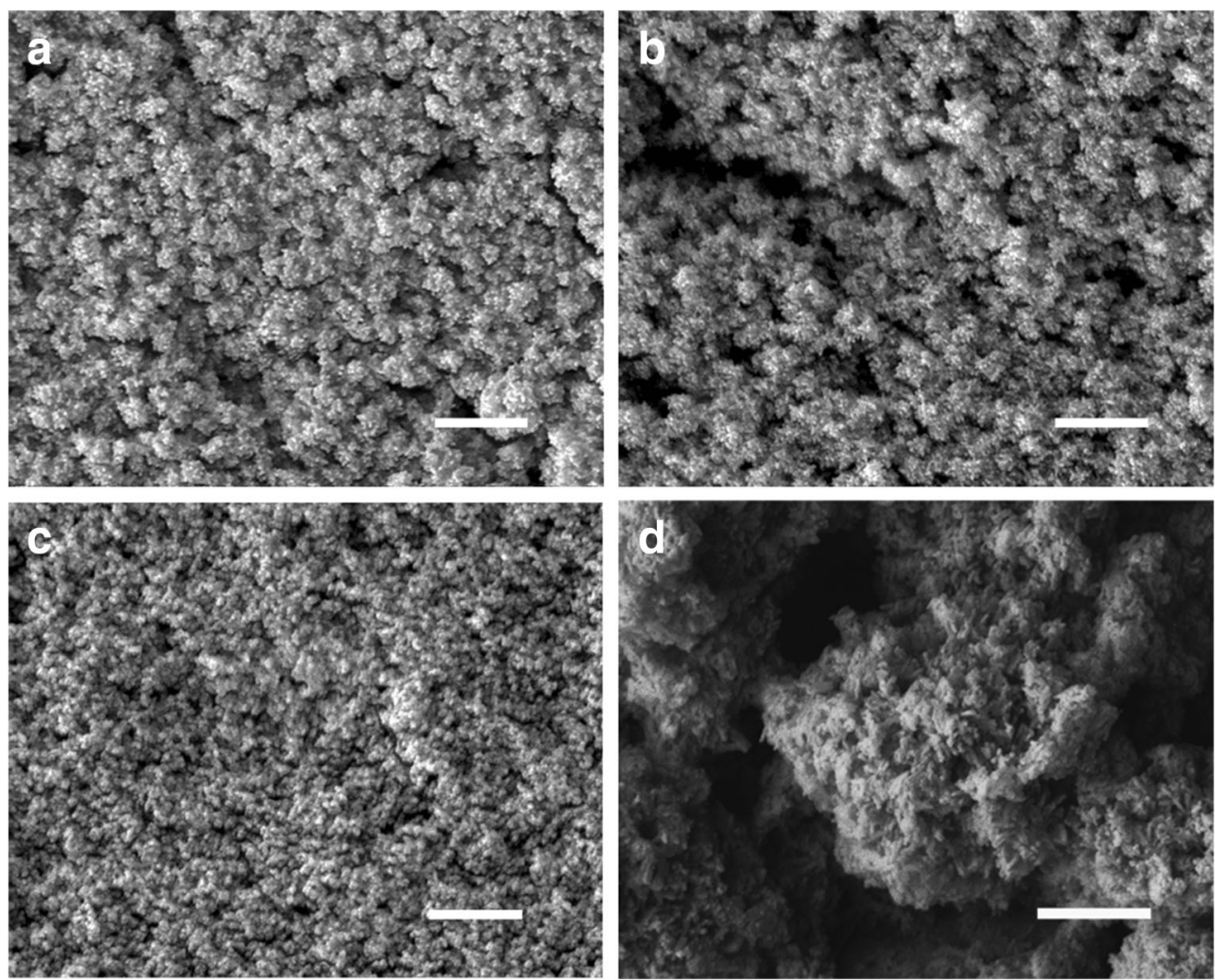
Table 3 Protein concentrations in different solutions and removal by the addition of $\mathrm{CO}_{3}{ }^{2-}$ and/or $\mathrm{Cu}^{2+}$

Protein source Concentration of protein in solution $\left(\mathrm{mg} \mathrm{ml}^{-1}\right.$; proportion of protein removed from the solution, \%)

\begin{tabular}{|c|c|c|c|c|}
\hline & Protein & Protein $+\mathrm{CO}_{3}^{2-}$ & Protein $+\mathrm{Cu}^{2+}$ & Protein $+\mathrm{Cu}^{2+}+\mathrm{CO}_{3}{ }^{2-}$ \\
\hline N. crassa & $14.90 \pm 0.33$ & $14.38 \pm 0.33(3.5)$ & $5.57 \pm 0.17(62.6)$ & $0.46 \pm 0.19(96.9)$ \\
\hline Pestalotiopsis sp. & $8.39 \pm 0.33$ & $8.07 \pm 0.12(3.8)$ & $5.03 \pm 0.09(40.0)$ & $0.13 \pm 0.05(98.5)$ \\
\hline M. gramineum & $22.47 \pm 1.71$ & $22.02 \pm 0.83(2.0)$ & $10.55 \pm 0.78(53.0)$ & $0.58 \pm 0.21(97.4)$ \\
\hline BSA & $32.55 \pm 0.67$ & $30.99 \pm 1.07(4.8)$ & $29.80 \pm 0.61(8.4)$ & $0.36 \pm 0.08(98.9)$ \\
\hline
\end{tabular}

All fungi were incubated in modified AP1 medium at $25^{\circ} \mathrm{C}$ in the dark for several days ( 12 days for N. crassa, 14 days for Pestalotiopsis sp. and 23 days for M. gramineum). To purify and obtain concentrated extracellular protein, fungal supernatant was centrifuged $\left(4770 \mathrm{~g} \times 30 \mathrm{~min}, 4^{\circ} \mathrm{C}\right)$ with a Vivaspin protein concentrator spin column (molecular weight cut-off 5000). Concentrated extracellular proteins/standard BSA solutions were mixed with $50 \mathrm{mM}$ $\left(\mathrm{NH}_{4}\right)_{2} \mathrm{CO}_{3}$, and then added to $50 \mathrm{mM} \mathrm{CuCl}_{2}$ for precipitation of copper carbonates. Measurements were taken from at least three replicates, and the values indicate the standard error of the mean

Acknowledgements The authors gratefully acknowledge the help of Dr. Yongchang Fan (Division of Physics, University of Dundee, Dundee, UK) for assistance with scanning electron microscopy, as well as Mrs. Sylvia Williamson and Dr. Aida Fuente Cuesta (School of Chemistry, University of St Andrews, St Andrews, UK) for assistance with Fourier transform infrared spectrometry.

\section{Compliance with ethical standards}

Conflict of interest The authors declare that they have no conflict of interest.

Funding Financial support in the author's laboratory is received from the Natural Environment Research Council (NE/M010910/1 (TeaSe); NE/M011275/1 (COG3)) which is gratefully acknowledged. We also acknowledge financial support from the China Scholarship Council through a PhD scholarship to Q.L. (No. 201206120066). G. M. Gadd also gratefully acknowledges an award under the 1000 Talents Plan with the Xinjiang Institute of Ecology and Geography, Chinese Academy of Sciences, Urumqi, China, and support from the National Natural Science Foundation of China (U1503281).

Ethical approval This article does not contain any studies with human participants performed by any of the authors.

Open Access This article is distributed under the terms of the Creative Commons Attribution 4.0 International License (http:// creativecommons.org/licenses/by/4.0/), which permits unrestricted use, distribution, and reproduction in any medium, provided you give appropriate credit to the original author(s) and the source, provide a link to the Creative Commons license, and indicate if changes were made.

\section{References}

Addadi L, Weiner S (1985) Interactions between acidic proteins and crystals: stereochemical requirements in biomineralization. Proc Natl Acad Sci U S A 82:4110-4114. doi:10.1073/pnas.82.12.4110

Addadi L, Moradian J, Shay E, Maroudas NG, Weiner S (1987) A chemical model for the cooperation of sulfates and carboxylates in calcite crystal nucleation: relevance to biomineralization. Proc Natl Acad Sci U S A 84:2732-2736. doi:10.1073/pnas.84.9.2732

Ahmad A, Mukherjee P, Senapati S, Mandal D, Khan MI, Kumar R, Sastry M (2003) Extracellular biosynthesis of silver nanoparticles using the fungus Fusarium oxysporum. Colloids Surf B: Biointerfaces 28:313-318. doi:10.1016/S0927-7765(02)00174-1

Aizenberg J, Addadi L, Weiner S, Lambert G (1996) Stabilization of amorphous calcium carbonate by specialized macromolecules in biological and synthetic precipitates. Adv Mater 8:222-226. doi: 10.1002/adma.19960080307

Alexeev D, Zhu H, Guo M, Zhong W, Hunter DJB, Yang W, Campopiano D, Sadler PJ (2003) A novel protein-mineral interface. Nat Struct Biol 10:297-302. doi:10.1038/nsb903

Arnold FH (1991) Metal-affinity separations: a new dimension in protein processing. Nat Biotechnol 9:151-156. doi:10.1038/nbt0291-151

Bansal V, Rautaray D, Ahmad A, Sastry M (2004) Biosynthesis of zirconia nanoparticles using the fungus Fusarium oxysporum. J Mater Chem 14:3303-3305. doi:10.1039/b407904c

Bansal V, Ramanathan R, Bhargava SK (2011) Fungus-mediated biological approaches towards 'green' synthesis of oxide nanomaterials. Aust J Chem 64:279-293. doi:10.1071/CH10343

Bhattacharya D, Gupta RK (2005) Nanotechnology and potential of microorganisms. Crit Rev Biotechnol 25:199-204. doi:10.1080/ 07388550500361994

Cava RJ (1990) Structural chemistry and the local charge picture of copper oxide superconductors. Science 247:656-662. doi:10.1126/ science. 247.4943 .656

Cha JN, Shimizu K, Zhou Y, Christiansen SC, Chmelka BF, Stucky GD, Morse DE (1999) Silicatein filaments and subunits from a marine sponge direct the polymerization of silica and silicones in vitro. Proc Natl Acad Sci U S A 96:361-365. doi:10.1073/pnas.96.2.361

Chandrasekharan N, Kamat PV (2000) Improving the photoelectrochemical performance of nanostructured $\mathrm{TiO}_{2}$ films by adsorption of gold nanoparticles. J Phys Chem B 104:1085110857. doi:10.1021/jp0010029

Cleverley JS, Bastrakov EN (2005) K2GWB: utility for generating thermodynamic data files for the Geochemist's Workbench ${ }^{\circledR}$ at $0-1000{ }^{\circ} \mathrm{C}$ and $1-5000$ bar from UT2K and the UNITHERM database. Comput Geosci 31:756-767. doi:10.1016/j.cageo. 2005.01.007

Dillon A, Mahan A, Deshpande R, Parilla P, Jones K, Lee S (2008) Metal oxide nano-particles for improved electrochromic and lithium-ion battery technologies. Thin Solid Films 516:794-797. doi:10.1016/ j.tsf.2007.06.177

Douglas T, Strable E, Willits D, Aitouchen A, Libera M, Young M (2002) Protein engineering of a viral cage for constrained nanomaterials synthesis. Adv Mater 14:415-418. doi:10.1002/15214095(20020318)14:6<415::AID-ADMA415>3.0.CO;2-W

El-Sayed MA (2001) Some interesting properties of metals confined in time and nanometer space of different shapes. Acc Chem Res 34: 257-264. doi:10.1021/ar960016n 
Falini G, Albeck S, Weiner S, Addadi L (1996) Control of aragonite or calcite polymorphism by mollusc shell macromolecules. Science 271:67-69

Ferris F, Phoenix V, Fujita Y, Smith R (2004) Kinetics of calcite precipitation induced by ureolytic bacteria at 10 to $20^{\circ} \mathrm{C}$ in artificial groundwater. Geochim Cosmochim Acta 68:1701-1710. doi:10. 1016/S0016-7037(03)00503-9

Flynn CE, Lee SW, Peelle BR, Belcher AM (2003) Viruses as vehicles for growth, organization and assembly of materials. Acta Mater 51: 5867-5880. doi:10.1016/j.actamat.2003.08.031

Gadd GM (2004) Mycotransformation of organic and inorganic substrates. Mycologist 18:60-70. doi:10.1017/S0269-915X(04)00202-2

Gadd GM (2010) Metals, minerals and microbes: geomicrobiology and bioremediation. Microbiology 156:609-643. doi:10.1099/mic.0. 037143-0

Gade A, Ingle A, Whiteley C, Rai M (2010) Mycogenic metal nanoparticles: progress and applications. Biotechnol Lett 32:593-600. doi: 10.1007/s10529-009-0197-9

Gallios GP, Vaclavikova M (2008) Removal of chromium (VI) from water streams: a thermodynamic study. Environ Chem Lett 6:235240. doi:10.1007/s10311-007-0128-8

Ghashghaei S, Emtiazi G (2013) Production of calcite nanocrystal by a urease-positive strain of Enterobacter ludwigii and study of its structure by SEM. Curr Microbiol 67:406-413. doi:10.1007/s00284013-0379-5

Gutiérrez R, Martín Del Valle EM, Galán MA (2007) Immobilized metalion affinity chromatography: status and trends. Sep Purif Rev 36: 71-111. doi:10.1080/15422110601166007

Hansen P, Andersson L, Lindeberg G (1996) Purification of cysteinecontaining synthetic peptides via selective binding of the $\alpha$-amino group to immobilised $\mathrm{Cu}^{2+}$ and $\mathrm{Ni}^{2+}$ ions. J Chromatogr A 723:5159. doi:10.1016/0021-9673(95)00806-3

He S, Guo Z, Zhang Y, Zhang S, Wang J, Gu N (2007) Biosynthesis of gold nanoparticles using the bacteria Rhodopseudomonas capsulata. Mater Lett 61:3984-3987. doi:10.1016/j.matlet.2007. 01.018

Horrocks WD Jr, Collier WE (1981) Lanthanide ion luminescence probes. Measurement of distance between intrinsic protein fluorophores and bound metal ions: quantitation of energy transfer between tryptophan and terbium (III) or europium (III) in the calcium-binding protein parvalbumin. J Am Chem Soc 103:28562862. doi:10.1021/ja00400a061

Huang SH (2006) Gold nanoparticle-based immunochromatographic test for identification of Staphylococcus aureus from clinical specimens. Clin Chim Acta 373:139-143. doi:10.1016/j.cca.2006.05.026

Huang C, Kerr PF (1960) Infrared study of the carbonate minerals. Am Mineral 45:311-324

Kaszuba JP, Runde WH (1999) The aqueous geochemistry of neptunium: dynamic control of soluble concentrations with applications to nuclear waste disposal. Environ Sci Technol 33:4427-4433. doi:10. 1021/es990470x

Klaus T, Joerger R, Olsson E, Granqvist CG (1999) Silver-based crystalline nanoparticles, microbially fabricated. Proc Natl Acad Sci U S A 96:13611-13614. doi:10.1073/pnas.96.24.13611

Kröger N, Deutzmann R, Sumper M (1999) Polycationic peptides from diatom biosilica that direct silica nanosphere formation. Science 286:1129-1132. doi:10.1126/science.286.5442.1129

Królikowska A, Kudelski A, Michota A, Bukowska J (2003) SERS studies on the structure of thioglycolic acid monolayers on silver and gold. Surf Sci 532-535:227-232. doi:10.1016/S0039-6028(03) 00094-3

Kumar A, Mandal S, Pasricha R, Mandale AB, Sastry M (2003) Investigation into the interaction between surface-bound alkylamines and gold nanoparticles. Langmuir 19:6277-6282. doi: $10.1021 / \mathrm{la} 034209 \mathrm{c}$
Kumari D, Qian XY, Pan X, Achal V, Li Q, Gadd GM (2016) Microbially-induced carbonate precipitation for immobilization of toxic metals. Adv Appl Microbiol 94:79-108. doi:10.1016/bs. aambs.2015.12.002

Lee SW, Mao C, Flynn CE, Belcher AM (2002) Ordering of quantum dots using genetically engineered viruses. Science 296:892-895. doi:10.1126/science.1068054

Li X, Xu H, Chen ZS, Chen G (2011) Biosynthesis of nanoparticles by microorganisms and their applications. J Nanomater 2011:1-16. doi: $10.1155 / 2011 / 270974$

Li Q, Csetenyi L, Gadd GM (2014) Biomineralization of metal carbonates by Neurospora crassa. Environ Sci Technol 48:14409-14416. doi:10.1021/es5042546

Li Q, Csetenyi L, Paton GI, Gadd GM (2015) $\mathrm{CaCO}_{3}$ and $\mathrm{SrCO}_{3}$ bioprecipitation by fungi isolated from calcareous soil. Environ Microbiol 17:3082-3097. doi:10.1111/1462-2920.12954

Li Q, Liu Z, Csetenyi L, Gadd GM (2016) Fungal biomineralizaiton of manganese as novel source of electrochemical materials. Curr Biol 26:950-955. doi:10.1016/j.cub.2016.01.068

Mandal D, Bolander ME, Mukhopadhyay D, Sarkar G, Mukherjee P (2006) The use of microorganisms for the formation of metal nanoparticles and their application. Appl Microbiol Biotechnol 69:485492. doi:10.1007/s00253-005-0179-3

Murray CB, Kagan C, Bawendi M (2000) Synthesis and characterization of monodisperse nanocrystals and close-packed nanocrystal assemblies. Annu Rev Mater Sci 30:545-610. doi:10.1146/annurev. matsci.30.1.545

Naik RR, Stringer SJ, Agarwal G, Jones SE, Stone MO (2002) Biomimetic synthesis and patterning of silver nanoparticles. Nat Mater 1:169-172. doi:10.1038/nmat758

Nudelman F, Sommerdijk NAJM (2012) Biomineralization as an inspiration for materials chemistry. Angew Chem Int Ed 51:6582-6596. doi:10.1002/anie.201106715

Pető G, Molnár GL, Pászti Z, Geszti O, Beck A, Guczi L (2002) Electronic structure of gold nanoparticles deposited on $\mathrm{SiO}_{\mathrm{x}} / \mathrm{Si}$ (100). Mater Sci Eng: C 19:95-99. doi:10.1016/S0928-4931(01) 00449-0

Phillips AJ, Gerlach R, Lauchnor E, Mitchell AC, Cunningham AB, Spangler L (2013) Engineered applications of ureolytic biomineralization: a review. Biofouling 29:715-733. doi:10.1080/08927014. 2013.796550

Poizot P, Laruelle S, Grugeon S, Dupont L, Tarascon J (2000) Nano-sized transition-metal oxides as negative-electrode materials for lithiumion batteries. Nature 407:496-499. doi:10.1038/35035045

Porath J, Carlsson JAN, Olsson I, Belfrage G (1975) Metal chelate affinity chromatography, a new approach to protein fractionation. Nature 258:598-599. doi:10.1038/258598a0

Ren G, Hu D, Cheng EWC, Vargas-Reus MA, Reip P, Allaker RP (2009) Characterisation of copper oxide nanoparticles for antimicrobial applications. Int J Antimicrob A G 33:587-590. doi:10.1016/j. ijantimicag.2008.12.004

Royston E, Ghosh A, Kofinas P, Harris MT, Culver JN (2008) Selfassembly of virus-structured high surface area nanomaterials and their application as battery electrodes. Langmuir 24:906-912. doi: 10.1021/la7016424

Ryu J, Kim SW, Kang K, Park CB (2010) Mineralization of selfassembled peptide nanofibers for rechargeable lithium ion batteries. Adv Mater 22:5537-5541. doi:10.1002/adma.201000669

Salunke BK, Sawant SS, Lee S, Kim BS (2015) Comparative study of $\mathrm{MnO}_{2}$ nanoparticle synthesis by marine bacterium Saccharophagus degradans and yeast Saccharomyces cerevisiae. Appl Microbiol Biotechnol 99:5419-5427. doi:10.1007/s00253-015-6559-4

Schweitzer PE (2004) Encyclopedia of corrosion technology, 2nd edn. CRC press/Taylor \& Francis Inc., New York

Seshadri S, Saranya K, Kowshik M (2011) Green synthesis of lead sulfide nanoparticles by the lead resistant marine yeast, 
Rhodosporidium diobovatum. Biotechnol Prog 27:1464-1469. doi:10.1002/btpr.651

Shaligram NS, Bule M, Bhambure R, Singhal RS, Singh SK, Szakacs G, Pandey A (2009) Biosynthesis of silver nanoparticles using aqueous extract from the compactin producing fungal strain. Process Biochem 44:939-943. doi:10.1016/j.procbio.2009.04.009

Shim HW, Jin YH, Seo SD, Lee SH, Kim DW (2010) Highly reversible lithium storage in Bacillus subtilis-directed porous $\mathrm{Co}_{3} \mathrm{O}_{4}$ nanostructures. ACS Nano 5:443-449. doi:10.1021/nn1021605

Sun HM, He WH, Zong CH, Lu LH (2013) Template-free synthesis of renewable macroporous carbon via yeast cells for high-performance supercapacitor electrode materials. ACS Appl Mater Inter 5:22612268. doi:10.1021/am400206r

Tranquada JM, Sternlieb BJ, Axe JD, Nakamura Y, Uchida S (1995) Evidence for stripe correlations of spins and holes in copper oxide superconductors. Nature 375:561-563. doi:10.1038/375561a0
Ueda EKM, Gout PW, Morganti L (2003) Current and prospective applications of metal ion-protein binding. J Chromatogr A 988:1-23. doi:10.1016/S0021-9673(02)02057-5

Weiner S, Addadi L (1997) Design strategies in mineralized biological materials. J Mater Chem 7:689-702. doi:10.1039/a604512

Wong JW, Albright RL, Wang NHL (1991) Immobilized metal ion affinity chromatography (IMAC) chemistry and bioseparation applications. Sep Purif Rev 20:49-106. doi:10.1080/03602549108021408

Wu ZS, Zhou G, Yin LC, Ren W, Li F, Cheng HM (2012) Graphene/ metal oxide composite electrode materials for energy storage. Nano Energy 1:107-131. doi:10.1016/j.nanoen.2011.11.001

Xie J, Zheng Y, Ying JY (2009) Protein-directed synthesis of highly fluorescent gold nanoclusters. J Am Chem Soc 131:888-889. doi: $10.1021 / \mathrm{ja} 806804 \mathrm{u}$

Zhang S (2003) Fabrication of novel biomaterials through molecular selfassembly. Nat Biotechnol 21:1171-1178. doi:10.1038/nbt874 